\title{
EXT2 wt Allele
}

National Cancer Institute

\section{Source}

National Cancer Institute. EXT2 wt Allele. NCI Thesaurus. Code C50959.

Human EXT 2 wild-type allele is located within 11p12-p11 and is approximately $150 \mathrm{~kb}$ in length. This allele, which encodes exostosin-2 protein, plays a role in the chain elong ation step of heparin sulfate biosynthesis. Certain allelic variants of the EXT 2 gene cause multiple exostoses type II. 